https://doi.org/10.18485/dpls_pld.2020.6.ch3

811.163.41'27

Đorđe Božović

Univerzitet u Beogradu

\title{
LINGVISTIČKI MARKERI REGIONALNOG IDENTITETA: POGLED IZ ŠTOKAVSKOG
}

Sažetak: U radu se predstavlja moguća paradigma istraživanja savremenog dijalekatskog stanja u jednom delu štokavskog narečja. Tradicionalna istraživanja raslojenosti jezika u prostoru motivisana su dijahronijski, što se odražava i na njihove ciljeve i metodologiju, dok su nešto noviji, sociolingvistički pristupi u domaćoj literaturi i dalje sporadični i mahom ograničeni na gradske varijetete. Na studiji slučaja novoštokavskih ijekavskih govora u jugozapadnoj Srbiji, analiziraćemo evoluciju tradicionalnog dijalekta u dodiru sa standardnim jezikom i ukazati na metodološke probleme koji se javljaju prilikom njegovog proučavanja, ali i na značaj koji takva istraživanja imaju kako za teorijsku lingvistiku - pre svega arealnu lingvistiku, sociolingvistiku ili tipologiju jezika; tako i za primenjene lingvističke discipline - poput forenzičke lingvistike ili odnosa standardnog jezika i dijalekta.

Ključne reči: artikulaciona baza, ,duboki“ i ,plitki“ dijalekat, razgovorni jezik, regionalni identitet, novoštokavski ijekavski govori u Srbiji, arealna lingvistika, sociolingvistika, forenzička lingvistika.

\section{Heraklov podvig}

Tokom prošlog veka - naročito u njegovoj drugoj polovini - do danas, dijalektologija je u našoj sistemi nauka o jeziku proživela možda $i$ najbrži i najveći razvoj. Od početaka, koje joj je pionirski zacrtao iznad svih Aleksandar Belić, kada je dijalektološka karta štokavskoga i susednih narečja bila praktično néma, danas na njoj gotovo da nêmā više većih belina (usp. Remetić 2017; Dragičević \& Remetić 2001, iz vizure srpske dijalektologije). 
Pa ipak, o trenutnom stanju štokavskih dijalekata, o arealnoj varijaciji u razgovornom jeziku kakva je ona pre svega kod sredovečnih i mlađih izvornih govornika danas (i kakva će se, prema tome, oblikovati i u ovom stoleću, u koje smo već prilično duboko ugazili; naime, uskoro će i najstarije informantkinje biti rođene u deceniji pred, tokom ili nakon Drugog sv. rata, prema tome i obrazovane u socijalističkoj Jugoslaviji, a njihove ispitivačice rođene pak u novom milenijumu - koliko to mora promeniti ,pravila igre“!) - ponovo kao da ne znamo gotovo ništa. Tako se i istraživanja regionalnih i lokalnih govora, kojih svakako ni danas ne manjka, često doimaju ponovo kao pionirska (usp. i Remetić 2017: 103$105 \mathrm{u}$ tom smislu, o reaktuelizaciji ,zavičajne dijalektologije“").

Izgleda kao da smo, dakle, obrnuli krug. U tome nema ničega neobičnoga, jer jezička je varijacija, prirodno, nesputana i emergentna; neminovno je bilo da će predmet istraživanja na taj način u jednom trenutku preteći i nadići svoju disciplinu - i to onda kada ga je opisala, on se, kao lernejska Hidra s kojom se sukobio Heraklo, opet pojavio za nijansu drugojačiji. I sasvim je normalno da radovi posvećeni regionalnoj varijaciji danas ponovno kreću postupno, malim koracima, od onog poznatoga dalje šireći horizont ka otkrivanju nepoznatog.

Ali, kao i Heraklov, i ovaj je zadatak sada unešto teže uhvatljiv, jer kao što bi Hidri na mestu jedne odsečene glave izrasle dve nove, tako se ni savremeno stanje prostorne varijacije na terenu štokavskoga ne može više lako opisati metodama tradicionalne dijalektologije. Zato što je dijalektologija bila posmatrana kao grana i pomoćna disciplina istorijske lingvistike (v. Brozović 2004), i njene metode su bile motivisane dijahronijski, kako pri izboru informatora, tako i u sastavljanju upitnika za lingvističke atlase, opisu samih idioma na terenu i, na kraju, pri analizi i sintezi tako prikupljene građe. Dijalektologija je u tome sve vreme vodila trku s modernizacijom, opisujući ono predmoderno stanje organih idioma koje još nije zahvatio sve jači uticaj standardnog jezika, tj. opšteg jezika javne komunikacije.

I u tome je uspela. Sinhronijski gledano, s obzirom na dob informatora, može se reći da dijalektološki opis štokavskoga narečja koji imamo predstavlja realno stanje teritorijalne varijacije kakvo je u njemu bilo na prelazu iz XIX u XX vek i tokom prve polovine XX veka, dakle pre većeg zamaha procesa modernizacije u svim aspektima društva i velikog projekta opismenjavanja najširih društvenih slojeva i njihovog uključivanja u javni diskurs, koji je do tada bio rezerviran tek za manji postotak 
stanovništva, činovničku klasu i inteligenciju. A od tada do danas je, u realnom vremenu, prošao ceo jedan vek - i to kakav vek. Vek intenzivnih migracija iz sela u gradove, vek progresa, elektrifikacije i industrijalizacije koja je obuhvatila gotovo sva naselja, pre svog sunovrata u poslednjih tridesetak godina, vek televizije i štampe, države blagostanja, svemirske utrke... Prema tome, ni informantkinjâ kakve je za sebe birala tradicionalna dijalektologija - što starije, nepismene, slabo pokretne tokom života u odnosu na mesto rođenja - uskoro neće postojati. Gotovo da već nigde više nema izvorne govornice štokavskoga koja nije pismena, u čiji dom nije ušao televizor ili makar radio, kao i sredstva daljinske komunikacije, koja ne komunicira s institucijama poput doma zdravlja, pošte, fonda PIO i dr. makar jednom mesečno, čija deca, unuke i unuci nisu migrirali iz mesta rođenja ili porekla roditelja makar u obližnje gradove, neretko i u drugi kraj zemlje, ako ne već i preko granice... I to u najkonzervativnijem slučaju - većina će pripadnica i pripadnika te generacije biti već i sami u gradu, imaće profesionalne karijere, čitaće knjige i pratiti masovne medije, putovaće i sretaće se ne samo sa standardnim jezikom i neformalnijim opštim vernakularom (koji nije „duboki“ dijalekat!) u svakodnevnoj komunikaciji, već i sa drugim varijantama tog jezika, u drugim republikama, kao i sa predstavnicima drugih narečja ili mesnih govora.

Tako, nema govornika štokavskoga koji nisu polifoni, zahvaljujući promenama koje je doneo kratki, ali ekstreman XX vek. Zato i Hidra jezičke varijacije s kojom se dijalektologija danas mora suočiti zaista ima - dve glave. Pored istorijskoga regionalnog ,supstrata“, koji je jedino interesovao tradicionalnu dijalektologiju, njena druga glava je sada upravo - organski upliv standardnog jezika. U novom odnosu snaga, dijalekat i naddijalekatski standard više ne koegzistiraju nezavisni jedan kraj drugoga, već sada predstavljaju organsku mešavinu. Govor čak i najstarijih, i tokom života najmanje pokretnih informantkinja danas jeste ili regionalno obojen (pod)varijetet (sup)standardnog jezika, ili mesni ili regionalni kolokvijalni govor pod uticajem standardnog jezika - u oba slučaja, kreolizirani „miks“ predmodernog i modernog idioma, samo s promenljivom koncentracijom osobina jednog ili drugog porekla, ali koje za izvorne govornike štokavskoga danas jednako predstavljaju njihov maternji, organski govor, koji se usvaja u porodici i upotrebljava u lokalnoj zajednici, kojim deca govore pre polaska u školu (a i tokom, pa najčešće i nakon školovanja) i kojim govore i njihove bake i deke. ${ }^{1}$

Stoga, bauk socijalizma, taj ,pitonski zagrljaj“ o kome govori i Remetić u napred cit. tekstovi- 
Uostalom, nešto slično je primetio još Belić, u svome pismu Baudouinu de Courtenay iz 1911. godine, nakon njihove zajedničke dijalektološke ekskurzije u Istri (Belić 1926/27):

„Čim dođem u neko selo, prva mi je dužnost da nađem dobre diale-
katske tipove. Jer nisu svi pretstavnici nekog govora dovoljno tipič-
ni. To ima, naravno, svojih dubokih razloga; ali to me se ovde sada
ne tiče. Za mene je samo neosporan fakat da ima ljudi koji govore
samo svojim dialektom i kod kojih ipak taj jedan jedini dialekat,
upravo, jezik nije izrazan, nije tipičan. Ja ne govorim o ljudima koji
su se malo mešali (a već danas ko se nije mešao?), već o onima koji
celog veka svog nisu nigde po svetu bili ili su još tako mladi da nig-
de nisu ni mogli biti. Ja odmah posle razgovora koji ne beležim, sa
ljudima i ženama, utvrđujem, u kojoj će se kući u selu tipično, razgo-
vetno, sa starim osobinama jezika (isp. niže) govoriti, i onda tražim
sve načine da se takvim kućama približim.“ (Belić 1926/27: 6)

Dakle, nisu čak ni svi govornici dijalekta dovoljno tipični predstavnici „starih osobina jezika“, čak i ako se nisu „mešali“ dalje od svog rodnog mesta i ako ne koriste druge govore osim svog mesnog idioma. A tek s uplivom ove moderne polifonije, škole i masovnih medija, ima li uopšte danas ,tipičnih“ govornica i govornika?

To pitanje jeste predmet ovoga rada. Na primeru novoštokavskih ijekavskih govora u jugozapadnoj Srbiji, razmotriće se mogući odgovori na pitanja: koji su to lingvistički markeri regionalnog identiteta, kako ih

\footnotetext{
ma, moraće još dugo progoniti domaću dijalektologiju, ali i uopšte sve grane nauke o jeziku koje svoja istraživanja zasnivaju na empirijskim proučavanjima realnog jezičkog stanja, čiji su nosioci današnji izvorni govornici i govornice, dakle generacije obrazovane tokom socijalističke modernizacije. Iako su i srpska (Ivić 2009) i hrvatska dijalektologija (Lisac 2003) proglasile „kraj istorije“, uzimajući kao fakat da „srpskohrvatskoga“ jezika više nema pošto nema Jugoslavije, pa se mogu baviti samo „organski srpskim“ odnosno „organski hrvatskim“ idiomima, točak istorije ipak upravo sada dovodi na scenu informante koji su obrazovani na zajedničkom književnom jeziku, čije je sve formativno lingvističko iskustvo jugoslovensko, pa srpskohrvatski jezik zapravo nikada nije ni bio stvarniji nego što je - upravo danas (usp. i Božović 2017). Paradoksalno, dakle, za onu dijalektologiju koja je opisivala govore pod nazivom „srpskohrvatska“ još bi se i moglo kazati da je proučavala „organski srpske“ i „organski hrvatske“ idiome; dok će ova dijalektologija danas, koja se piše kao „srpska“ i „hrvatska“, u stvari neminovno proučavati upravo - dijalekte srpskohrvatskog jezika, tj. razgovorne inačice i idiolekte njegovih izvornih govornika, nikad stvarnijih nego sad, koji su taj jezik usvajali u kontekstu socijalističke izgradnje društva i tako pretvorili upravo u „organsku“ lingvističku stvarnost, a koji nastavlja da živi u sferi kulturne nadgradnje i nakon raspada političke zajednice i za one mlađe govornice i govornike rođene i nakon sloma SFRJ. Istorijska ironija je, tako, učinila da „srpskohrvatski jezik“ ne samo da nije uopšte stvar prošlosti, već je naša realna sadašnjost $i$ budućnost u nauci.
} 
istražiti i šta nam oni govore o odnosu između tradicionalnih dijalekata i standardnog jezika. Kako su ovo problemi koje domaća lingvistika nije dovoljno - praktično nije uopšte - izučavala, to se razume da ni ovde neće moći da budu ponuđeni neki opsežniji odgovori na njih, već samo moguće smernice, u iščekivanju budućih, podrobnijih i temeljnijih istraživanja savremene teritorijalne raslojenosti razgovornog jezika. Osim za samu nauku o jeziku, odgovori na ova pitanja jesu i od velikog praktičnog značaja - u svima onima domenima profesionalne delatnosti u vezi s jezikom koji moraju obratiti pažnju na regionalnu varijaciju kakva je ona u aktuelnom trenutku kod sredovečnih i mlađih govornika i govornica, npr. u sociolingvistici - u obrazovnim jezičkim politikama, metodici nastave maternjeg jezika i standardizaciji jezika; u forenzičkoj lingvistici i fonetici - u često neizbežnom profilisanju i identifikaciji govornika na osnovu regionalne pripadnosti tokom istrage ili sudskog postupka, i sl.

Drugim rečima, bez znanja o aktuelnoj regionalnoj varijantnosti u govornom jeziku ne samo što gubimo u pogledu što potpunijeg poznavanja, pa tako i boljeg razumevanja jezičkog fenomena, što je svakako interes nauke, nego rizikujemo i narušavanje kvaliteta života ljudi, koji bi zbog nedostatka aktuelnih naučnih saznanja i mogućnosti njihove primene u rešavanju konkretnih praktičnih problema mogli trpeti realne posledice u ostvarivanju svojih građanskih i ljudskih prava, a što je pak u suprotnosti sa interesom društva u celini.

\section{Studija slučaja: novoštokavski ijekavski govori jugozapadne Srbije}

U pogledu dijalekatske raslojenosti, Srbija obuhvata prilično heterogen teren - nešto su manje dubòke dijalekatske razlike nego u Hrvatskoj (koja je i geografski tako postavljena da se različiti delovi zemlje pružaju u različitim pravcima, pa tako i zahvataju sasvim različita istorijska narečja i dijalekte), ali su primetno veće nego u Crnoj Gori ili Bosni i Hercegovini (opet, najpre zahvaljujući tom spoljašnjem faktoru - samoj geografiji: površini, položaju itd.). Tako su se u Srbiji stekli: 1) na jugoistoku od standardne štokavštine tipološki najudaljeniji prizrensko-timočki dijalekti, 2) u izduženoj središnjoj zoni u dolini Ibra i severoistočno preko Morave i Dunava troakcenatski ekavski govori kosovsko-resavskog i smederevsko-vršačkog dijalekta, 3) na severu i zapadu zemlje je četvoroakcenatski šumadijsko-vojvođanski dijalekat ekavskog izgovora, te na jugozapadu 4) 
govori novoštokavskog (istočnohercegovačkog) i 5) starijeg štokavskog (zetsko-sandžačkog) ijekavskog dijalekta. ${ }^{2}$ To dijalekatsko šarenilo, koje se produžava i u susedne govore preko granica zemlje (s kojima i tradicionalno održava svaka od ovih zona privredne i demografske veze, pa otuda i arealnolingvističke), natkriljeno je pak jednom standardnojezičkom varijantom u javnoj i službenoj upotrebi, s novom akcentuacijom i ekavskoga izgovora (ali koja nije sasvim identična ni šumadijsko-vojvođanskoj akcentuaciji i ekavštini, niti istočnohercegovačkoj akcentuaciji).

Odnosi standardnoga jezika sa svakom od ovih dijalekatskih zona imali su u svakoj i različit kvalitet i kvantitet. Prvo, usled faktora same tipološke razlike između njih i standarda, koja je najmanja u novoštokavskim, a najveća u prizrensko-timočkim dijalektima. I drugo, iz istorijskosocioloških razloga, jer nisu predstavnici i predstavnice svake od ovih dijalekatskih zona u jednako vreme primali pismenost, niti se u njima istovremeno i jednakim intenzitetom gradila mreža škola i puteva te pokrivenost medijima; delom i zato što nisu ni sve ove oblasti u isto vreme postale deo države Srbije, a te dublje razlike su se zadržavale i kasnije. Stoga se dodir standardnog jezika sa svakim od ovih dijalekata u Srbiji može (i treba) proučavati i kao poseban fenomen, ali i komparativno, što je jedan od zadataka za buduću dijalektologiju (usp. u tom smeru jedno moguće sociolingvističko istraživanje o dijalektima na jugoistoku Srbije u Petrović 2015).

Mi smo odabrali novoštokavske ijekavske govore u jugozapadnoj Srbiji, budući da su tipološki veoma bliski standardu (to za razliku od sandžačkih govora, koji su takođe jekavski, ali starije fizionomije), a s druge strane (za razliku od novoštokavskih ekavskih govora dalje na severu) ipak nisu percipirani kao deo njega, pre svega zato što su drukčijeg izgovora. Iako je standardni srpski jezik ravnopravno ekavskog i ijekavskog izgovora, u Srbiji se u državnoj administraciji, školama i medijima u praksi dosledno koristi samo ekavica, kako na prostoru većinskih ekavskih, tako i na terenu naših ijekavskih govora. ${ }^{3}$ Svi govornici i govornice ovog

\footnotetext{
${ }^{2}$ Osim ovih krupnijih zona, u Srbiji ima i manjih govornih oaza poput ,jatovskih" govora na terenu šumadijsko-vojvođanskog dijalekta ili bunjevačkih ikavskih govora na krajnjem severu. Pored toga, ove dijalekatske oblasti, sa izuzetkom jedino istočnohercegovačke, nisu ni fizički sasvim kompaktne, kao što se to obično predstavlja na kartama, već su gdegde i bitnije prošarane i razbijene drugim jezicima - bilo to neslovenskim idiomima poput albanskoga na jugu, vlaškog odnosno rumunskog na severoistoku, mađarskog na severu, te romskog, bilo to i, u Vojvodini, naseljima s drugim slovenskim jezicima (rusinskim, slovačkim, makedonskim itd.). To za posledicu ima i značajnije prisustvo bilingvizma pa i plurilingvizma u nekim slučajima, što dodatno usložnjava pomenutu heterogenost jezičkog pejzaža Srbije.

${ }^{3}$ Standardnojezičke varijante ijekavskog izgovora u upotrebi su u susednim republikama Bosni i
} 
dijalekta, dakle, opismenjavaju se na ekavici i koriste ekavski izgovor danas u svim sferama javne, ali i privatne komunikacije, gde pak ona koegzistira sa ijekavskim (ali, što je važno, ne sa standardnojezičkim nego sa dijalekatskim ijekavskim) oblicima.

Kako je reč o perceptualno i sociolingvistički markiranoj razlici u refleksima jata, a s druge strane o tipološki relativno bliskim idiomima na svim nivoima jezičke strukture (zbog čega se i mogu isključiti razni drugi faktori, sa kojima bi se pak moralo računati kada je reč o prizrensko-timočkim ili staroštokavskim dijalektima), analiza ovih govora može nam pružiti vredne uvide $u$ to kakav je odnos ,dubokog“ dijalekta i standarda, tj. koja su to lingvistička obeležja koja izvorni govornici i govornice percipiraju kao dijalekatske, a koja ne, koje su to osobine dijalekta koje se čuvaju i uprkos uticaju standardizacije, i zašto, te kako teče proces aproprijacije standardnog jezika od strane izvornih govornika i govornica tipološki relativno bliskog, ali ujedno i markiranog dijalekta u odnosu na standard (tj. ono što je u praksi realno postojeći standard - ekavština). Za to nam, jasno, neće biti adekvatne metode tradicionalne dijalektologije, koju zanima samo ,čisti“ oblik „dubokog“ dijalekta, već je nužno da dijalekat posmatramo kao aktuelni, živi vernakular te sredine, kao varijantu razgovornog jezika.

Opet, na nečemu sličnome je svoju metodologiju zasnivao i Belić, koji nas u nastavku pisma obaveštava da je predmet njegovog proučavanja - ono što sami govornici i govornice „osećaju kao osobinu svoga govora", dakle njihova metalingvistička svest o dijalektu:

„Jer meni su potrebni dvojaki tipovi: jedni koji će mi davati material i drugi koji će ga verifikovati zajedno sa mnom. Pored toga što ja takvom verifikovanju sa strane urođenikove verujem tek onda kada se sa različnih strana uverim da je tako, meni je ipak vrlo potrebno da se upoznam sa onim što oni osećaju kao osobinu svoga govora. / Sve tipove sa kojima počnem da radim, a koji su uopšte dovoljno tipični, ja ispitujem sa različnih strana, naročito sa gledišta jezičkoga osećanja koje u njima treba razviti do pune svesnosti." (Belić 1926/27: 6-7)

Hercegovini i Crnoj Gori, gde se nalazi i glavnina i žarište ijekavskih govora čiji su ovi srbijanski ogranak, što je pak još jedan razlog, u spletu složenih sociolingvističkih okolnosti na višenacionalnom prostoru srpskohrvatskog jezika, zašto se i „domaća“ ijekavica na terenu Srbije (auto) percipira kao drugačija.

${ }^{4}$ Za razliku od potonje dijalektologije, koja je tražila što starije informatore, zanimljivo je da Belić dijalekatski materijal rado prikuplja od govornika i govornica svih uzrasta kod kojih je dovoljno 
Tako usmerene analize ijekavskih govora u Srbiji su značajne i sa stanovišta tipološke i dokumentarističke lingvistike, budući da je ovo jedini takav odnos između dijelekatske baze i standarda na celoj štokavskoj teritoriji, gde je ijekavska baza, a ekavski prestižni idiom. Na više mesta u raznim delovima štokavskog narečja ima ekavskih ili polu(j)ekavskih govora u dodiru sa ijekavskim standardom (u Crnoj Gori, Bosni i Hercegovini i poglavito u Hrvatskoj), ali odnos ijekavska dijalekatska baza : ekavski superstrat postoji samo ovde. (Ako se izuzmu kolonisti nosioci istočnohercegovačkog dijalekta u Vojvodini, jer oni tu ipak čine manjinski nanos na terenu drugog dijalekta, a ovde je sama dijalekatska baza istočnohercegovačka.) Iz takvog odnosa nastao je (i morao je nastati) i nov kvalitet - vernakular koji nije jednak niti toj dijalekatskoj bazi, a ni ekavskom prestižnom idiomu. Naime, za njega tradicionalni ijekavski dijalekat ima ulogu supstrata, dok ekavski standard ispunjava ulogu superstrata pod čijim je uticajem. Ali ne dešava se prosta zamena ijekavskog dijelekta ekavskim ili zamena dijalekta standardnim jezikom, kako je taj odnos uglavnom tuma-

razvijena (meta)lingvistička svest:

„Veliki deo, inače dobrih dialekatskih tipova, za to je prosto nesposoban; ali često se nailazi na tako zahvalan material da se ja i sada kada Vam ovo pišem sećam svojih mladih i starih filologa-seljaka, devojčica od 12-13 god., mladića od 17-20 god. ili još mlađih, i, najzad, starijih ljudi - koji su za kratko vreme tako ulazili u stvar da su u rečenice, koje sam ja na njihovu dijalektu sastavljao, gotovo sa apsolutnom pouzdanošću umetali onu reč ili onaj oblik koji su u njima nedostajali, a koje sam hteo imati. Ja se sa velikim zadovoljstvom sećam, naročito, mališana i devojčica koji su posle dužih vežbanja sa mnom odlazili kućama i sami pronalazili nešto u svome jeziku što su mislili da mi valja saopštiti. Ovde bi se moglo govoriti o potrebi, koju često ističu dijalektolozi, da se jezičke crte beleže od pretstavnika nekog govora različnog uzrasta: od dece, mladića, devojaka, ljudi i žena srednjeg doba i, najzad, staraca i starica. Ali to je, u tolikoj meri, potrebno samo onda kada se ispituje isključivo dialekat jednog mesta, jednog sela; a kada se ispituju dialekti većih geografskih obima, onda je dovoljno naznačiti da se neki oblici naporedo upotrebljavaju. Po celokupnome razvitku jezičkih crta danih govora biće jasno koje su crte tih govora novije, a koje starije. Tako ćemo moći u sintezi pratiti ono što bi nam, često vrlo teško izvodljivo, ispitivanje dialekta svakog sela na naročito po uzrastu određenim tipovima pružalo u analizi.“ (Belić 1926/27: 7)

Umesto rigorozne metodologije, koja će klasifikovati ispitanike i ispitanice po polu, uzrastu, društvenom statusu i sl. u različite grupe, kao recimo u sociolingvistici labovljevskog tipa, Beliću je, izgleda, važnije da pronađe pre svega „dovoljno tipične“ dijalekatske tipove, a zatim da i unutar njih dobije one „filologe-seljake“ kod kojih se jezičko osećanje može „razviti do pune svesnosti“ tako da sami svedoče o svom govoru, ma kog roda, uzrasta ili statusa bili (ali ne i „mesnu inteligenciju“, koja je, „sem izuzetnih slučajeva, samo smetala“; Belić 1926/27: 6). 
čen u tradicionalnoj dijalektologiji (v. i niže), već upravo u toj interakciji ijekavskoga supstrata i ekavskog superstrata nastaje i nov govorni jezik, tj. novi dijalekatski varijetet (poput nekog „srednjeg sloga“"). Taj varijetet jeste predmet i našeg istraživanja, a pre nego što mu se detaljnije obratimo, izložićemo najpre bliži teorijski okvir za takvo njegovo sagledavanje, a potom i pregled dosadašnjih istraživanja ove govorne zone.

\subsection{Teorijsko-metodološki okvir}

Kao što je već bilo reči u uvodnom delu rada, u fokusu je tradicionalne dijalektologije bio isključivo „duboki“ dijalekat. Za savremeno stanje regionalne varijacije u jeziku, kao i za konkretna praktična pitanja u vezi s regionalnim raslojavanjem, uključujući tu i naše govore, relevatniji su, međutim, ,plići“ nivoi vernakulara - dijalekatski obojen (sup)standardni jezik i regionalni kolokvijalni govor, dakle upravo dijalekatski kreoli „,srednjeg sloga“ koji nastaju u interakciji dijalekatske baze kao supstrata i standardnog jezika.

U tom smislu, teritorijalna varijacija je zapravo uvek društvenoteritorijalna varijacija. Umesto samo jedne dimenzije u prostoru, ona je dvodimenzionalna - pored horizontalne, ima i vertikalnu osu. (Treća dimenzija, ona vremenska, priključuje se prvoj ili obema u dijahrono usmerenim istraživanjima; ali i ona je, zapravo, društveno posredovana.) Usp. u tom smislu i izrazito elaboriran Muljačićev (1996; s tamo cit. literaturom) pristup romanskim jezicima. To će reći da su „organski“ idiomi zapravo uvek proizvod „kreolizacije“ neke vrste između neke supstratne baze, koja je i sama nastala na taj način, samo u nekom ranijem periodu, i nekog ,višega“", prestižnog idioma, superstrata ili adstrata, u odnosu na koji govornici „pregovaraju“ svoj jezički identitet. ${ }^{5}$ Stoga su i metode sociolingvistike

\footnotetext{
5 To je otuda što je takvo (re)modelovanje inherentno samom govoru; pa i ultimativni uzrok varijacije i promene u jeziku. Naime, jezik se uvek ostvaruje u društvenoj zajednici, bilo da je ona minimalna kao jedno selo, bilo da je to neka šira demografska skupina ljudi koji u nekom prostoru stupaju u dodir. Ali samim tim što je reč o grupi ljudi, unutar nje moraju postojati i individualne razlike u govornom izrazu, pa čak i da nisu drugačije nego samo anatomski i psiholingvistički uslovljene. Pošto „pregovaranje“ individualnih razlika jeste osnovni mehanizam funkcionisanja svake ljudske zajednice, to znači i da će neke od tih individualnih razlika biti više, a neke manje vrednovane, tj. da će za sve ili samo za neke od govornika i govornica u zajednici nužno u tom procesu govorni izraz neke pojedinke ili pojedinca poneti prestiž. To ljudsko ponašanje u krajnjem ima evolutivnu osnovu, i ljudi ga dele s drugim primatima. Tako, do prilagođavanja neke „supstratne“ baze unutar zajednice (bilo da je reč o približavanju ,poželjnoj“, dakle o konvergenciji između govornika, ili o distanciranju od neke manje ,poželjne“ osobine, tj. o divergenciji u lingvističkom smislu i posledičnom „,cepanju“ jezičke zajednice) mora da dođe čak i u izolovanim
} 
(odn. tzv. „urbane“ dijalektologije) potrebne i u proučavanju svih regionalnih, ne samo gradskih varijeteta. U našoj zajednici, one su, međutim, izuzetak i mahom su ograničene samo na urbani kontekst (za vrlo dobar pregled istraživanja u tom ključu, cf. Bjelaković 2018) ili pak na stavove prema standardnom jeziku, prema vlastitom i drugim dijalektima. (Jedno od retkih istraživanja kod nas koje u ispitivanje stavova uključuje i dinamiku odnosa dijalekta i standarda te sociolingvističkog prestiža, koji ne mora biti nužno ograničen na standardni jezik, jeste Kovačević 2005; za naš slučaj je ovaj rad značajan i zato što tretira upravo odnos ijekavske baze i ekavskog standarda. Takođe je za naš pristup vredno pomena i istraživanje Sudimac 2016, utemeljeno u sociofonetici.)

Dakle, i aktuelno stanje regionalne varijacije u štokavskome neophodno je posmatrati u tom dvo- odnosno trodimenzionalnom kontekstu, tj. kao društvenoteritorijalnu varijaciju u govoru konkretnih pojedinki i demografskih skupina ljudi, što će reći kao stanje promene u konkretnim idiolektima, situiranim u određenom društvenom kontekstu na nekom društveno posredovanom prostoru. Realni predmet proučavanja varijacije, tako, postaje idiolekt, jer se u njemu dešava ta promena. Pitanje je koje odlike „dubokog“ dijalekta se zadržavaju u govoru obrazovanih pojedinaca, i zašto, odnosno kada pojedinci odlučuju da govore dijalektom i da na taj način konstruišu i komuniciraju (tj. , pregovaraju“") regionalnu pripadnost. (Za pristup dijalektu kao izboru koji polifoni govornici i govornice prave u konkretnim komunikativnim situacijama zalaže se i Petrović 2016, odn. u ranije pomenutoj studiji.)

\footnotetext{
govornim zajednicama (u tom slučaju, unutar njih - jer, ni izolovane govorne zajednice, makar i bile jezički konzervativnije, ipak ne prestaju da se menjaju), a naročito, kao što je u ljudskim društvima običniji slučaj, u dodiru nosilaca različitih varijeteta. U tom smislu, i svaki govorni varijetet je uvek neki ,srednji slog“, a prostorna varijacija u jeziku je uvek društveno posredovana varijacija, jer do nje uopšte i ne dolazi zbog nekih osobina samog prostora, kako se nekad ustvrdi u geolingvistici (npr. zbog neke objektivne geografske distance i sl.), nego zahvaljujući tome što ljudi žive $u$ zajednicama na nekom prostoru, tj. samo zahvaljujući tome što neke zajednice ljudi omeđuju neke prostore, pa se onda i mehanizmi koji u stvari deluju unutar i između njih očituju na nekom tako omeđenom prostoru u odnosu na druge zajednice, koje su pritom i u stalnom kretanju. Otuda i ta trodimenzionalnost prostora i vremena. To je važno i ovde istaći, jer se često prostor (pa i vreme) u lingvistici shvataju kao statične i jednodimenzionalne fizičke datosti, a one to nikada nisu. Zato je u bilo koje istraživanje jezičke varijacije u prostoru i vremenu neophodno uključiti i društvenu dimenziju, ako želimo da što potpunije razumemo jezički fenomen. Sami prostorni odnosi, u smislu fizičke ili političke geografije, o jeziku ne govore ništa po sebi. (Zato je i moguće da promenom fizičkih odlika terena, pa ni samom promenom državnih granica, ne nestanu niti da nastanu automatski i nove govorne zajednice, već je odlučujući način na koji su one društveno situirane, dakle konkretan kontekst u kome su se formirale, tj. sami realni ljudi koji ih u određenom istorijskom trenutku čine i njihova konkretna istorijska iskustva. Usp. Božović, op. cit.)
} 
Takva istraživanja idiolekta sasvim su nova u našoj sredini i, što je zanimljivo, nisu se javila primarno iz ugla sociolingvistike i/ili dijalektologije (mada u zadnje vreme ima i takvih inovativnih istraživanja, v. pre svega radove u Bošnjaković 2009, ali i Bošnjaković 2016, kao i veoma zanimljivo istraživanje dijalekatskog ujednačavanja u Sredojević \& Čopa 2018), već iz potreba prakse i istraživačkih interesovanja u domenu forenzičke lingvistike i fonetike, pre svega u radu Zorke Kašić i saradnica (cf. Kašić, Jovičić \& Đorđević 2008; Kašić \& Đorđević 2009a; konkretno o forenzičkim markerima regionalne pripadnosti Kašić \& Đorđević 2009b; Ivanović \& Šešum 2009; te najskorije Lončar Raičević \& Sudimac 2017). Osim toga, pitanja savremene regionalne varijacije i jezičke akomodacije pokreću se i u istraživanjima pisanog jezika u novim tehnologijama i novim medijima (Ljubešić, Miličević Petrović \& Samardžić 2019; i. a.), koji predstavljaju izuzetno bogat (i nepresušan) izvor nove građe.

Dakle - kada govorimo o dijalekatskoj varijaciji, govorimo pre svega o kontinuumu između „dubokog“ i ,plitkog“ dijalekta, tj. o razgovornom jeziku najvećeg dela govornika i govornica neke dijalekatske oblasti (ne samo onih najstarijih, po mogućstvu nepismenih i sa margina svih društvenih kretanja, već upravo onih, odraslih i dece, koji jesu aktivni subjekti u govornoj/društvenoj zajednici i jesu uključeni u tokove društva, u kojima i performiraju svoj jezički/regionalni identitet - aktivno ga konstruišu u jeziku, a nas kao lingviste i lingvistkinje zanima upravo kojim lingvističkim sredstvima to čine). ${ }^{6}$ Tako, opis govora nije ni mehanička

\footnotetext{
6 Tradicionalna dijalektologija bi mogla ovakvom metodološkom određenju zameriti da se tako mogu propustiti neke arhaične crte govora, koje su bitne $u$ istorijskoj perspektivi i bitne za razumevanje njegove geneze odn. za klasifikaciju, a koje se možda još čuvaju samo kod tih najstarijih informatora, skrajnutih od inovacija (uostalom, zato je ona i birala baš takve). Ali, pri tome ona gubi iz vida dve stvari. Prvo, činjenicu da je svaki, pa i govor tih informatora, takođe „srednji slog", i da bez obzira na to koje informatore bira, dijalektološkinja uvek opisuje u stvari upravo u tom (ili u najboljem slučaju, ako uzmemo u obzir starosnu dob njenih najstarijih informatora $-\mathrm{u}$ nekom tek neposredno prethodećem) trenutku aktuelan sinhronijski presek; ona nikada nije zaista dijahronijska disciplina (jer za razliku od istorijske gramatike, dijalektologija ne rekonstruiše, nego opisuje upravo stanje koje jeste sinhrono i sa samim trenutkom ispitivanja; na kraju, svi njeni informatori su u tom trenutku živi ljudi) i, u najboljem slučaju, ona uspeva samo da neznatno pomeri taj presek za nekih pedesetak godina u prošlost, čime stvara tek iluziju dijahronije. Npr. opis štokavskih dijalekata kakav sada imamo jeste samo realna slika varijacije kakva je bila na prelazu iz XIX i dalje kroz XX vek, dakle u tom konkretnom vremenu; on nam ne može reći šta je uopšte bilo pre. Uostalom, i onda kada se zaista bavi dijahronijom, kao što je to npr. Pavle Ivić radio kao vrsni utemeljivač istorijske dijalektologije u nas, ona to uvek čini ili pomoću dodatnih materijala (pisanih spomenika, etnografskih i istorijskih izvora itd.), ili uz pomoć dodatnih metoda (strukturalne analize, lingvističke geografije i dr.). A drugo, i bez obzira na to kakve informatore bira, u svakom slučaju će biti ,[p]o celokupnome razvitku jezičkih crta danih govora [...] jasno koje su
} 
radnja, niti je sam ,govor“ neki unapred dat i nezavisno od nas postojeći entitet koji se samo nalazi „tamo negde“, čekajući da ga dijalektolog zabeleži, već je konstantno ,pregovaranje“ između samih pripadnika i pripadnica jedne govorne zajednice, kao i između njih i ispitivača. To je, vek ranije, intuitivno shvatao i Belić, kada je tražio ne samo ,tipične“, već upravo i one dijalekatske tipove čije je jezičko osećanje razvijeno „do pune svesnosti"6.

\subsection{Dosadašnja proučavanja}

Iz tradicionalne dijalektologije, a jednako o tome svedoče $\mathrm{i}$ istorijski, antropografski i etnografski izvori, znamo da je ijekavski novoštokavski dijalekat u Srbiju intenzivno unošen neprekidnim prilivom pretežno stočarskog stanovništva dinarske migratorne struje iz istočne i Stare Hercegovine (tzv. Erâ), u kojoj se taj dijalekat bio oformio (v. o tome više u Ivić 2001). Reč je o izrazito metanastazičkoj oblasti, u kojoj gotovo da i nema starinaca (ili su se i sami prethodno iseljavali na sever, ili su iseljeni kao muslimansko stanovništvo u sukobima tokom ustanaka u Srbiji i zauzimanja Užica i Sokola 1862. godine, ili je sam kraj i uopšte bio slabije naseljen). Tako, i ovi govori u Srbiji dele sve osnovne odlike istočnohercegovačkog dijalekta (njegove jugoistočne polarizacije) - ijekavsku (u dugim slogovima dvosložnu) zamenu jata sa najnovijim jotovanjem $l j$,

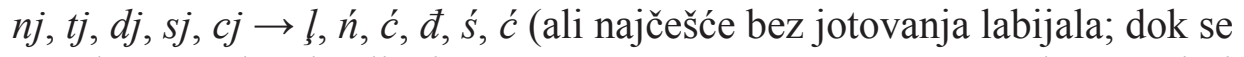
$z j$ uglavnom depalatalizuje $\rightarrow z$, npr. ìzutra prema śütre, mada poznaju i alofon $z$ ), te novu akcentuaciju sa dobro očuvanim (i još negde razvijenim i novim, npr. pred sonantom u pridevskim sufiksima $-\bar{o} v / \bar{e} v,-\bar{a} v$, pridevskom i imeničkom -īn itd., ali ne ako vokal nije deo sufiksa ili se morfološki tako ne oseća: zèlen, jädan, jàlov, tako i jèdan i sl., kao i u sufiksima -āst, deminutivnom -īć, ali ne i patronimičkom, itd.) postakcenatskim dužinama i sistemskim prenošenjem akcenta na proklitičke predloge, rečce i veznike ( i na brojeve (dvá dana, pèd godīnā).

Od fonoloških crta, pored zamene jata i akcentuacije, znaju još i za rotacizam že $\rightarrow$ re ( $m$ örem, pa kârēe), krazu ao $\rightarrow \bar{o}$, zev se i inače ne trpi, pa su obične i elizije (dùzmē, nùmijē), obično nema frikativa $f$ (sem

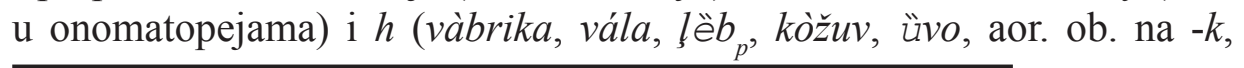

crte tih govora novije, a koje starije“, kako je to primetio Belić (op. cit.). Osim toga, dijahronijsku perspektivu je u dijalektologiju uvek moguće uvesti i ponovnim opisom nekoga govora nakon izvesnog protoka vremena. 
gen. pl. zam. na -ig, òras i u sg. analoški prema pluralu, stio za m. r. sg. gl. prid. radn.), preglas $o: e$ je u gubljenju (pútom, nóžom), uprošćavaju se finalne grupe $-s t,-\check{s} t,-z d \rightarrow-s,-\check{s},-z$ (jës za duži oblik 3. lica sg. gl. jesam) i neke druge ( $b$ ïdē običnije nego $b$ İdnê, süjē i šèn ${ }^{i} c a$, ali tkâm), okazione disimilacije $m n \rightarrow m l$ i $v n$, haplologija u kùruz, analoška afereza u vâmo (ali ònomo, sa asimilacijom vokala, nasuprot analoškim gòrāmo, dòlāmo, pored göre i döl̦e), ${ }^{7}$ metateza u vóđe, protetičko $j$ - i apokopa u jöpe (nisu dovoljno istražene ovakve apokope, pa i glotalizacije finalnih ploziva, tipa Màčkas $\leftarrow$ Mačkat), a s poslednjim u vezi, i obezvučavanje finalnih zvučnih opstruenata ( $s$ äd, Pàlisāt, llë $b_{p}$ i sl.), itd. I druge konsonantske alternacije su ovde sistemske i produktivne, kao sinhronijski živi fonološki procesi (Ràdēnci, ù_Požezi i dr.), i deluju i u sandhiju (kao i nakon raznovrsnih sinkopa, tipa sà`šćōm $\leftarrow$ sa srećom), a i analoški se uopštavaju (3. 1. pl. prez. vúčù i sl.).

Od morfoloških crta, tu su i infinitiv na -ti i -ći, aorist i imperfekt, enklitičko $b i$ za sva lica, nova deklinacija i promena muških imena na -o i -e po I vrsti (Péro : Péra, Pérōv itd.), instrumental je poopšten s predlogom $s$, enklitika $v i$ u dativu 2. lica množine (ali ne i $n i$, ve i ne), dativ/ lokativ zamenica mène, tèbe, sèbe i prisvojne njózi, kraće forme s predlozima tipa zá se, u tvorbi gl. prid. trpnog uopštava se - $t$ uz osnove na - $a$; a u sintaksi, prisvojni genitiv plurala (naročito u mikrotoponimiji), redak je $u+$ prisv. gen. (posesija se običnije iskazuje konstrukcijom s gl. imati),

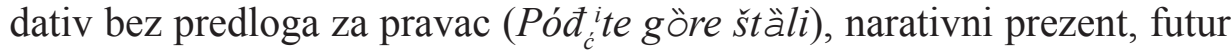
i imperativ, infinitiv češće nego $d a+$ prezent (a i kada ga menja $d a+$ prezent, enklitike ostaju ,podignute“ kao uz infinitiv: oće ga da vidi; ili se i inače češće smeštaju iza glagola umesto na „drugoj“ poziciji, naročito to važi za povratnu se: $d a$ vidi se).

Iz pragmatike, tu su partikule -(r)e, -ke, -no $\leftarrow$ ono itd. uz priloge, veznike i zamenice ( $k$ äde, naske pored nas, štäno i štànō, đëno i đènō, po istom akcenatskom obrascu je i ènē m. èno; u izolaciji se jednosložne

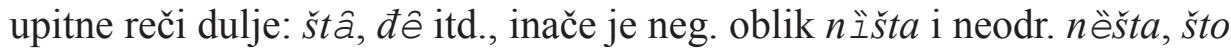
samo i uvek kao odnosna zamenica). Ljudi se između sebe oslovljavaju sa kône (u vok. se zadnji slog uvek dulji kada je reč u emfazi) ili neskraćenim kòmšija i kòmšīnka (nisu obični jadan, bolan i sl.), ugl. muškarci između sebe u dijalekatskom žargonu (takođe jednom slabije opisanom sociolingvističkom varijetetu naših dijalekata) sa $p r i ̂ l e, p r i ̈ k a(\leftarrow p r i j a-$ telju), brâle i bürāz ( $\leftarrow$ brate, odn. burazeru), iz poštovanja i honorifikom

\footnotetext{
Usp. i analizu sistema adverba u Marković (2016), s mnogo bogatijom građom.
} 
$g a ̈ z d a+$ ime; a ako su u rodbinskoj vezi, onda terminima srodstva ( $b a ̈ b a$, strîna, čìča, iz milošte strikane, đédo, vok. đêdo, újko, vok. lijko, đéšo, vok. đêšo $\leftarrow$ đever itd.; među ovim terminima srodstva dolaze i neki vokativi m. r. jednaki nominativu, kao: đë_si röđāk, sinòvac). Muškarci u pravilu imaju nadimke i od ličnog imena i od prezimena (te nadimke nose čitave porodice; ovde nisu obični patronimici tipa Stefan Mitrov, već toga-i-toga sin/snaja/zet/unuk..., ili je porodični nadimak dovoljan da označi rodovsku pripadnost), a oni mogu, ali i ne moraju uopšte biti u tvorbenoj vezi sa tim imenima; dok žene imaju samo hipokoristike od ličnog imena ako je ono dugačko (Rada, Caka, Boba), inače takve nadimke u pravilu nemaju, i ako ih imaju, to je onda kada na neki način izlaze iz rodne uloge, bilo nekim svojim ponašanjem ili karakteristikom, bilo zato što se bave „muškim“ poslovima, npr. trgovinom (Mŕsivōjka, Zóra Čùčkuša je generičko ime za radoznalu osobu), već se po pravilu određuju preko muževljevog imena (tip Vesna Mićina) ili porodičnim imenom, odnosno mocionom izvedenicom od njega (Òvōje näša Božòvkuša, Crepùlārka $\leftarrow$ Crepuljarević i sl.). - I ovi pragmalingvistički i antropolingvistički fenomeni svakako zavređuju dodatna istraživanja, jer nisu u tolikoj meri prisutni u tradicionalnoj dijalektologiji (koja radije elicitira monologe informanata, upućene ispitivaču, nego što ispituje njihovu međusobnu konverzaciju); zato smo im ovde i dali malo veći prostor.

Sa crnogorskim ijekavskim govorima (staroštokavskim) ovi govori dele, pored nekih od iznad navedenih osobina (i naročito - $g$ kao jedne od zamena za $-h$ ), i sporadičnu zamenu $d \rightarrow j$ (u čestici goj) i slabiju artikulaciju sonanta $j$ ne samo u međuvokalskom položaju nego i na kraju reči (imper. nèmō i sl.), a sa susednim bosanskim redukcije nenaglašenih

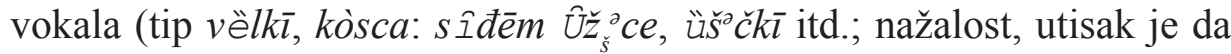
postojeći opisi ovih govora uopšte ne beleže odnosno nevodoljno precizno beleže ovakve prozodijske pojave na supfonemskom nivou), kao i zatvoreniji izgovor dugih vokala, te sufikse -ero i -erica pored -oro i -orica, što nisu osobine tako obične u ostalim istočnohercegovačkim govorima ovoga (istočnog) tipa.

Retke su izoglose, ali vredne pomena, koje ove govore povezuju s ekavskim govorima na istoku, poput prisvojne zamenice njin ili toga da, za razliku od drugih ijekavskih govora, ovde nisu obični bez proširenja ne oblici prez. gl. tipa sretem i rečem. Uz poneke osobenosti u akcenatskim paradigmama, one ovim govorima ipak daju onu nešto „blažu“ srbijansku notu i pored njihove sveukupne istočnohercegovačke fizionomije. 
Od autentičnih osobina, tj. onih kojima se ne povezuju s nekim drugim kompleksom ijekavskih govora izvan Srbije, imaju uvek (neuslovljenu poziciono) velarizovanu artikulaciju sonanta $l$. Zanimljivo je da je ovo i jedna od najranije uočenih osobina ovih govora, još i pre dolaska naučne dijalektologije na ovaj teren, već u Milićević 1876: 631, što svedoči o njenoj perceptivnoj istaknutosti, s jedne strane, slično kao i u dijalektološkoj literaturi ono poznatije, postalveolarno ,adrijatičko “ $l$ u nekim drugim dijalektima i jezicima u susedstvu, a s druge strane, i o tome da bi, opet slično kao i postalveolarno $l$, kao automatizam artikulacione baze moglo da posluži i kao forenzički marker. Slično vredi i za nazalizovan izgovor, koji je stalna karakteristika nekih govornika (ugl. muškaraca, dok se ženski glasovi odlikuju vibratom - ni ovo, nažalost, nisu dovoljno istražene pojave na prozodijskom planu; iako ih i sami govornici između sebe neretko, recimo u slučaju nazalizacije, uspešno percipiraju, pa i imitiraju kada impersoniraju tuđe glasove).

I to je, dakako, skica ovog „dubokog“ dijalekta samo u grubim crtama, dok detaljnije opise konkretnih govora (koji se mogu i razlikovati u ponekim osobinama ili sistemu osobina od izloženih opštih crta) imamo u Gorobilju kod Užičke Požege (Nikolić 1972), Lještanskom (Tešić 1977), srbijanskom Polimlju (Nikolić 1991), Dragačevu (Đukanović 1995) i u užičkoj Crnoj gori (Marković 2011), te tri monografske studije koje tretiraju neki izolovani fenomen - reflekse jata u okolini Priboja (Đurović 1980), granicu između ijekavskih i ekavskih govora u Srbiji (Marković 2012) i, najskorije, akcenatski sistem Zlatibora (Lončar Raičević 2018), kao i, naravno, nîz kraćih priloga, crtica, analiza i sl. (najskorije Marković 2019). (A tome bi svakako trebalo dodati i punktove Kriva Rijeka na Zlatiboru i Pakovraće kod Čačka, koji su ispitani za potrebe izrade Opšteslovenskog lingvističkog atlasa, v. u Ivić 1981; kao i rečnik u Cvijetić 2014.)

U svima, pa i najranijima, od opisa ovih govora, primećena je manje ili više česta (u zavisnosti od informatora) pojava ekavizama. To je i osobina u kojoj se ovi govori najbrže i najmarkantnije menjaju udaljujući se od iznad opisane „duboke“ dijalekatske baze, već duže od sto godina, ali dijalektološka literatura nam ne nudi nedvosmisleno i obuhvatno tumačenje ove pojave. U starijoj literaturi, naime, ovaj proces je tumačen kao zamena jednog dijalekta drugim. Tako ga veoma slikovito opisuje, recimo, još Erdeljanović (1902):

„Stanovništvo govori vrlo pravilnim srpskim jezikom i u glavnom južnim narečjem. Ali se već jako oseća i uticaj istočnog narečja, 
tako da se neke reči već nikako i ne govore po južnom nego samo po istočnom narečju. Za druge pak reči, a negde i za veliki broj reči, govore se oba oblika, pa nije retko čuti, da ih jedan isti čovek upotrebljava. Ovo gubljenje južnoga narečja ima se pripisati nadmoćnome uticaju istočnog narečja, koji mu daje njegova zvanična upotreba. U školi, u crkvi, kod vlasti i u vojsci, pa zatim i u varošima uopšte narod svuda čuje samo istočni govor, i onda nije čudo, što je dosta od njega primio. Svud se zapaža i to, da stariji ljudi govore pravilnije a neki i sasvim pravilno južnim govorom - znak, da istočno narečje prodire jače tek u novije doba. I među pojedinim selima ima u tome razlike: neka su očuvanija neka više podlegla ovom uticaju." (Erdeljanović 1902: 99-100)

Sasvim slično govori i Moskovljević (1929), tridesetak godina kasnije:

„Bilo je vreme kad je jekavski govor bio vrlo ekspanzivan, najekspanzivniji od svih drugih naših govora. [...] Ali je davno prošlo vreme njegove ekspanzije, i on se sve više povlači pred navalom ekavskog izgovora. [...] U toku poslednjih sto godina jekavski izgovor je uzmicao pred navalom ekavskog i danas se čisto jekavski govori jedino u užičkom okrugu: u podrinskom okrugu imamo samo uzan pojas jekavskog na desnoj strani Drine, u rudničkom je skoro potpuno preovladao ekavski, a u čačanskom se još samo u manjem, zapadnom delu čuje pretežno jekavski. [...] Što jekavski izgovor sve više uzmiče ispred ekavskog ovo su razlozi: / 1.) Politički. S jačanjem i modernizovanjem države sve je jači njen uticaj na stanovništvo. Državne vlasti, vojska i škola utiču da se sve više širi ekavski izgovor na štetu jekavskog, tim lakše što drugih razlika skoro i nema. / 2.) Ekonomski. Varoši, koje su kao političko-kulturni centri prve prihvatile ekavštinu, budući uz to i ekonomski i saobraćajni centri, utiču na svoju jekavsku okolinu kao rasadnici ekavštine. / 3.) Socijalni. Jekavci zauzimaju neplodnije planinske krajeve, a ekavci ravnije i plodnije. Sa svojih brda jekavci silaze na rad u ravnije krajeve i ja sam posmatrao u podrinskom okrugu, a tako je verovatno i u drugim, da meštani s visine gledaju na „Jadrane“, kako nazivaju sve brđane-jekavce, smatrajući ih prostijim, gorim, i kad hoće da im se rugaju oni izgovaraju pojedine reči po jekavski i upotrebljavaju njihovu uzrečicu ,bojse“. Stoga je razumljivo što jekavci izbegavaju da govore jekavski.“ (Moskovljević 1929: 109, 112, 122) 
Te tako i Ivić za njima navodi: „Ipak je u nauci poznato da na sektoru od Kraljeva do Drine ovaj dijalekat [= šumadijsko-vojvođanski] dobija sve više terena, potiskujući jekavski istočnohercegovačkog tipa“" (Ivić 2001: 91). Međutim, to ni u kom slučaju nije tačno. S jedne strane, zato što su i novija istraživanja (Marković 2012) potvrdila kako se granica ijekavskih govora u zapadnoj Srbiji praktično nije uopšte pomerila u poslednjih sto godina - „duboka“ ijekavska baza je i dalje onde gde ju je manje-više ocrtao i Moskovljević: u užičkom okrugu, uzanom pojasu uz Drinu i u zapadnim delovima čačanskog okruga. S druge strane, teorija o zameni istočnohercegovačkog dijalekta šumadijsko-vojvođanskim nije ispravna ni zato što se promene koje se u ovom dijalektu dešavaju tiču samo refleksa jata, a glavnina svih drugih osobina u fonologiji i prozodiji, morfologiji i sintaksi u njima ostaje istočnohercegovačka čak i onda kada je zamena jata u potpunosti ekavska. Ne dolazi, dakle, do zamene dijalekta, već samo do ekavizacije (ili ,dejekavizacije“) ijekavskih refleksa jata unutar onoga što su i dalje čitavom svojom fizionomijom govori istočnohercegovačkog dijalekta. To i jeste naš ,,srednji slog“, kvalitativno nov vernakular - ekavski (tačnije: ekaviziran) istočnohercegovački govor ili ekavski razgovorni jezik na istočnohercegovačkoj dijalekatskoj bazi.

Bliži takvom razmišljanju bio je Peco (1980), mada se, s druge strane, ni sa njegovom teorijom o ekavskom supstratu ovih govora ne bismo mogli u potpunosti složiti:

„Ranije je ijekavština duboko sezala u zapadnu Srbiju. Misli se da je dopirala čak do Morave. [...] Danas više nije tako ni u Vukovom Tršiću. Ali, to takođe treba istaći, ima još uvek u tom delu Srbije ijekavskih govornih celina. Takav je skoro ceo zlatiborski kraj. [...] Ijekavizam je dosta stabilan u međusobnom razgovoru meštana. U kontaktu sa drugim ljudima, kako uočava Miroslav Nikolić [= i.e. Nikolić 1972], lako se prelazi na ekavski izgovor, i što je „značajno“ oni „svoj govor osećaju kao dijalekatski“. To je danas činjenica koja se ne može prevideti. [...] Još da istaknemo i to da se ovi govori nikako ne mogu smatrati prelaznim između jekavskih i ekavskih govora, mada bi se, na osnovu njihovog današnjeg stanja, i takav zaključak mogao izvući. Prvo, to su migracioni govori, znači oni su tu doneseni iz južnijih krajeva i, što je takođe značajno, nisu ni ranije bili potpuno kompaktni. I ranije je bilo tu ekavskog življa, i ranije je bilo tu ekavizama u govoru jekavaca, negde manje, a negde više. Prema tome, ti su govori, makar i činili teritorijalnu vezu sa 
jekavcima južnijih krajeva, uklešteni među ekavce i dobrim delom se nalaze na iskonskom ekavskom tlu. Drugo, gubljenje njihovoga jekavizma posledica je ne vlastite evolucije nego spoljnih uticaja koji ovamo donose standardni ekavski govorni obrazac. U procesu tih ukrštanja još će se dugo čuvati neke tipično jekavske odlike, kako u fonetici, tako i u prozodiji i morfologiji. Tako će se desiti da ćemo u tom regionu imati ekavski izgovor kao standardni, ali će mnoge njegove gramatičke kategorije odisati jekavskom strukturom." (Peco 1980: 79-81)

Upravo, ne bi se za ove govore smelo reći ni da je reč o prelaznim ekavsko-jekavskim govorima. Iz dva razloga. Prvo, zato što oni nisu zaista prelazni govori poput novopazarskih, koji jesu proizvod kontakta između dveju dijalekatskih baza, ekavske i ijekavske, a ne jedne „duboke“ dijalekatske baze i standardne ekavštine. I drugo, zato što su upravo zbog različite takve evolucije i porekla njihovih ekavizama „odozdo“ odnosno „odozgo“, sandžački govori kao prelazni ujednačeni u svojim ekavskojekavskim refleksima jata, a ovde paralelno postoje oba izgovora, tako da su govornici i govornice u takvoj „slobodnoj mešavini“ dvoizgovorni te mogu da biraju hoće li, kada i sa kim upotrebiti ijekavske ili ekavske oblike, tj. preključuju se između onog govora koji sami „osećaju kao dijalekatski“" i onoga koji ne osećaju kao takav. ${ }^{8}$

Prema tome, nemoguće je razumeti prirodu ovog vernakulara i pojavu ekavizacije u njemu bez uključenja sociolingvističke perspektive, tj. bez razlikovanja ,visokog“ i ,niskog“ stila, fenomena preključivanja koda i sl. (usp. sada i Trajković 2017 na tome tragu, s tamo cit. literaturom), kao ni bez perspektive dijalekatske pragmatike, kao što je to hteo i Belić, tj. otkrivanja samog jezičkog osećanja govornika. Jer, izbor koji

\footnotetext{
8 Naravno, interesantno bi bilo istražiti i kako se sandžačka ekavsko-jekavska dijalekatska baza ponaša u dodiru sa standardom, bilo da je on srbijanski ekavski, bilo da je ijekavski u crnogorskom delu Sandžaka ili i u Srbiji za tako nacionalno opredeljene sandžačke Bošnjake. Ali, to je umnogome daleko složeniji slučaj; i zato što je sama dijalekatska baza tipološki udaljenija od standarda, ne samo u pogledu refleksa jata, i zato što je razdeljena na dve ili tri države, i zato što je nekoliko standardnojezičkih varijanata koje govornici i govornice ovog dijalekta biraju kao implicitno (stvarno) prestižne ili kao eksplicitno prestižne (kao obeležja identiteta), što može, ali i ne mora da se podudari: ekavska u Srbiji, crnogorska ijekavska u Crnoj Gori, bosanska ijekavska u Srbiji, bosanska ijekavska u Crnoj Gori, kao i zato što postoje efekti kontakta sa drugim jezicima (albanski, turski), a i na kraju, ali ne i najmanje važno, zato što je čitav ovaj jezički pejzaž, ionako komplikovan, dodatno usložnjen različitim političkim opredeljenjima unutar same zajednice i različitim konstrukcijama pa tako i načinima ,pregovaranja“ nacionalnog, konfesionalnog, regionalnog i dr. identiteta.
} 
između ekavskih ili ijekavskih refleksa jata prave izvorni govornici istočnohercegovačkoga dijalekta u jugozapadnoj Srbiji nije kao neke druge osobine govora nesvestan, već je za njih sociolingvistički obeležen, i prema tome pragmatski regulisan, svestan izbor. To primećuju i gotovo svi ispitivači ovog dijalekta cit. iznad. Pitanje je, dakle, kada i kako, tj. koja lingvistička sredstva koja imaju na raspolaganju (,kulturnu“ ekavštinu ili dijalekatsku ijekavštinu), različiti konkretni govornici i govornice ovog dijalekta odlučuju da unesu u diskurs.

\subsection{Savremeno stanje}

O tome da se ne radi o zameni, tj. povlačenju jednog u korist drugoga dijalekta, već o kvalitativno drugačijem fenomenu interferencije između „dubokog“ dijalekatskog supstrata i uzornog standarda, svedoči i činjenica da se ni danas, nakon više od jednog stoleća delovanja toga procesa, ijekavski dijalekat ipak nije izgubio. S druge strane, ni standardni jezik izgleda da nije uspeo da istisne dijalekat, što je druga pretpostavka s kojom je operisala tradicionalna dijalektologija tokom druge polovine XX veka, žureći da opiše govore dok ih književni jezik nepovratno ne izbriše.

Standard, tačnije neki njegovi elementi, jesu se uselili u dijalekatsku reč, ali umesto da dokinu regionalne razlike, izgleda da su govornicima i govornicama samo ostavili izbor da u većoj ili manjoj meri jezikom komuniciraju (ili, manje ili više uspešno, sakriju) regionalni identitet. Teorija o hijerarhijskom odnosu između standarda i dijalekata se, tako, krajem XX veka ispostavila kao pogrešna (usp. Kenda Jež 2004). Posebno zanimljivo istraživanje donosi Smole (2004), koja je, na terenu slovenačkog jezika, istraživala istinitost tvrdnji da dijalekti izumiru, da su predstavnici dijalekta isključivo neobrazovani i manje obrazovani ljudi, da su dijalekti karakteristika ruralnih a ne urbanih sredina, da se dijalektom govori samo u privatnoj sferi, tj. unutar porodice, da mlađe generacije ne govore ili sve manje govore dijalektom i da su žene bolje predstavnice dijalekta nego muškarci, itd. Većina ovih uverenja ispostavljaju se netačnim ili tek delimično tačnim.

Zašto dijalekti ne nestaju? Zašto se granica ijekavskih govora u zapadnoj Srbiji, kako to pokazuju i najskorija istraživanja (v. iznad), nije značajnije pomerila? Kako to da ni sama ijekavica, kao najmarkiranije obeležje ovih govora, ni nakon više od sto godina ekavizacije, nije dosada već postala davna prošlost, već se opis situacije koju je zatekao i Erdelja- 
nović pre više od jednoga veka (,za veliki broj reči, govore se oba oblika, pa nije retko čuti, da ih jedan isti čovek upotrebljava“) apsolutno doima kao i nama savremen i danas aktuelan, kao da nije čak tada, nego tek juče zabeležen?

Naravno, to je zato što aktuelna dinamika odnosa standard : dijalekat, onako kako se ona prelama kroz idiolekte i konkretne govorne prakse savremenih govornika i govornica u razgovornoj reči (,,plitkom“ dijalektu), nije dinamika zamene - niti jednog dijalekta drugim, niti dijalekta standardnim jezikom - već dinamika preključivanja i performativnog nivelisanja onoga što sami govornici osećaju kao dijalekat i onoga što ne osećaju tako. Ona omogućava da dijalekti ne nestanu, ali ni da se povuku u privatnu sferu, već upravo da isplivaju kao takvi onda kada njihovi govornici žele da postignu neformalnost situacije, tj. da ostvare koheziju unutar zajednice i da pošalju poruku o ravnopravnosti sa sagovornicom (koja se, u uslovima ovakve konstrukcije standardnog jezika, i ne može drugačije poslati jezičkim sredstvima nego upravo njihovim oslobađanjem od stega „pravilnosti“, tj. onoga što sami govornici osećaju kao eksplicitnu jezičku normu). Tada je dijalekat sredstvo ,pregovaranja“ identiteta, kojim se šalje poruka „mi smo deo iste grupe/jednaki“, $\mathrm{i}$ to performativno sredstvo, jer se njime taj cilj i ostvaruje. Prema tome, uloga standarda se u tome ispostavlja kao paradoksalna - umesto da potisne dijalekte, upravo sámo postojanje standarda i njegov upliv u idiolekte „odozgo“, kao eksplicitna norma koja je namerila preko škole, medija i dr. da smeni dijalekte stigmatizujući ih kao „nepravilne“, omogućava da dijalekat zadobije takvu funkciju i ne da nestane ili da se povuče, nego da se konzervira kao sredstvo „normalizacije“ diskursa i da kao takvo ostane na raspolaganju govornicima i govornicama. ${ }^{9}$ „Jedan isti čovek“, kako primećuje Erdelja-

\footnotetext{
9 Dijalekat se, između ostalog, - pored toga što služi kao sredstvo „pregovaranja“ identiteta, pa se funkcionalno i pragmatički specijalizuje i zbog toga ne nestaje, - i stalno iznova obnavlja. Zanimljiv primer nam daje Smole u pomenutom istraživanju: „Poznam kar precej takih primerov; nenazadnje spada mednje tudi moja mama. V času zaposlitve je bila kot narečna informatorka nezanesljiva, saj je v službi redno preklapljala v nadnarečno pogovorno različico. Šele po nekaj letih upokojitve se je vrnila $\mathrm{v}$ sistemski narečni različek in znala $\mathrm{v}$ njem tudi razpoznavati nenarečne prvine“ (Smole, op. cit: 328). To je, po svemu sudeći, i mehanizam međugeneracijskog prenošenja dijalekta, s deka i baka, koji u starosti, nakon što pritisci modernizacije na njih kao na sada neaktivne članove društva oslabe, a moguće i zato što inače različite sposobnosti, među kojima je i jezička samoregulacija, uopšte zanemoćaju, ponovo progovore dijalektom, na njihove unuke. To i svi ispitivači ovih govora primećuju kao češću pojavu dijalekta kod starijih informatora, a njegovo odsustvo kod mlađih, ali to preuranjeno tumače kao znak gubljenja dijalekta, previđajući da će i ti mlađi, kada ostare, progovoriti dijalektom svojih deka i baka, i preneti ga na svoje unuke. Zato se stanje i nije značajno promenilo u odnosu na vek ranije, jer su tadašnji mladi u međuvremenu
} 
nović, zato i može da upotrebi i jedne i druge oblike, upravo u zavisnosti od govorne situacije.

Ali, da bi se dijalekatski oblici, čija je funkcija sada identitetska i kohezivna, uopšte pojavili u diskursu, potrebno je da sagovornik bude deo zajednice. Zato ispitivači ovih govora uglavnom primećuju da ijekavski ljudi govore ,između sebe“ ili u privatnoj sferi, jer to tako izgleda iz ugla ispitivača. Ne govori se dijalektom nužno samo u privatnoj sferi, već se govori $u$ zajednici, kojoj ispitivač najčešće ne pripada. Zato se njemu čini kao da se dijalekat povlači i zato se može desiti i da, ma koliko dugo boravio u mestu čiji govor ispituje, uopšte i ne čuje tražene dijalekatske forme (sve dok se, eventualno, informatori ne obrate jedni drugima). To je i razlog zašto je Belić, kako nas obaveštava u pomenutom pismu (Belić 1926/27), uvek pre nego što ode na teren sâm pokušavao da savlada govor koji će opisati i da se na njemu obraća svojim informatorima - ne zato što ga oni ne bi razumeli drugačije, nego zato da bi ga, što je to više moguće, percipirali kao člana zajednice. To nije samo „posmatračev paradoks", već i efekat socijalnog identiteta, koji je nekada i nepremostiv metodološki problem. Jer, osim što i sámo prisustvo ispitivača, kao osobe sa strane, može da inhibira pojavu dijalekatskih formi čak i ako informatori u tom trenutku razgovaraju između sebe, među faktorima koji utiču na izbor koda biće, pre svega, i sâm sastav grupe ljudi na konkretnom mestu, a mogućno i njena veličina, odnos između sagovornikâ i dr. Ne manje važan je stav govornika prema ijekavštini, koji je posredovan društvenom stigmom i drugim činiocima o kojima govori i Moskovljević (v. iznad), pa će tako većina govornika i na eksplicitno pitanje da li je njihov govor ijekavski kategorički tvrditi da nije i čuditi se tome pitanju (,to je u Crnoj Gori“ ili „u Bosni“; neki će, u najboljem slučaju, priznati da je to „seljački“", da tako govore „babe“ ili da se tako govori u susednom selu - obavezno imitirajući i prozodiju ,is $\square$ Kremānā", „,iz Murtenice“" i sl. - koje figurira kao personifikacija autostereotipa, ali to samo zato da bi poentirali kako se tu tako ne govori) - samo da bi pak, trenutak kasnije, spontano izgovorili neki ijekavski obrt. Upravo je stoga pristup tradicionalne dijalektologije, koja samo „objektivno“ beleži ono što zatekne na terenu, nedostatan i pomalo naivan - ona, kako je to iznad istakao Peco,

postali stari, oslobođeni pritiska modernizacije, i obnovili dijalekat za svoje unuke, koji su pak do sada već i sami postali deke i bake i taj isti dijalekat od pre jednoga veka prenose novoj generaciji govornika, koja njime možda još uvek i sama ne govori, i neće, sve dok i sama ne dobije unuke. Ali zato živućih i aktivnih govornika i govornica dijalekta uvek ima i proces njegovog prenošenja se u svakom trenutku odvija. 
ne bi smela prevideti činjenice sociolingvistike i dijalekatske pragmatike. A s druge strane, stoga je i ona odranije pomenuta „zavičajna“ dijalektologija zapravo neretko i najbolji način da ispitivačica, budući ravnopravna članica govorne/društvene zajednice pred kojom se informatori neće prikrivati, ne bi ni samim svojim prisustvom sprečila pojavu dijalekta i tako donela pogrešne zaključke.

Drugo, to otvara mogućnosti istraživanja toga šta zapravo sami govornici i govornice percipiraju (,osećaju“) kao dijalekatsko, a šta ne. Jer, nisu sve odlike „dubokog“ dijalekta na isti način markirane, te tako i nastaje naš „,srednji slog“, tj. ,plitki“ dijalekat, živi razgovorni vernakular koji predstavlja osnovu savremene regionalne varijacije na terenu štokavskoga. U njemu, ono što govornici ne percipiraju kao osobinu svog dijalekta ili ono što je automatizam artikulacione baze takođe ostaje kao lingvistički marker regionalnog identiteta; samo što, za razliku od onoga što se percipira kao dijalekatsko, ovde nije reč o performativnim sredstvima „pregovaranja“ identiteta, već o njegovim stabilnim, objektivnim markerima.

Kako u pogledu toga stoje naši govori? Sama zamena jata može biti i performativna, svesna odlika dijalekta, ali i nesvestan objektivni marker regionalnog identiteta u slučajevima u kojima je ijekavski refleks jata „skriven“, najčešće nekom drugom glasovnom alternacijom, pa se ne prepoznaje kao takav. Dvosložni refleks dugog jata je, kao i strukurno najsloženiji, i najmarkiraniji u tom pogledu i prvi podložan ekavizaciji. Za njim sledi refleks kratkog jata i s njim povezano jekavsko jotovanje, a na kraju refleks $i$ pred vokalom, jer se ovaj neretko i ne percipira kao refleks jata. Ta skala markiranosti je vidljiva i u toponimiji, gde su, na prostoru koji je prvi ušao u sastav Srbije, ijekavski toponimi najpre ekavizovani ukoliko sadrže refleks dugog * ě: Bijela Rijeka $\rightarrow$ Bela Reka i Kriva Rijeka $\rightarrow$ Kriva Reka na Zlatiboru, ali Đetinja, gde je refleks *ě sakriven jotovanjem, ili u imenu sela Bioska, gde je *ě $\rightarrow i$. Takav „skriveni jat“ će se javiti i u rečima koje su vezane za materijalnu kulturu i običaje u lokalnoj zajednici i koje kao takve nemaju (adekvatnog) dvojnika u standardu: kùđeļa, póśek (svinjokolj). Uvek ijekavski su i kl’éšta, žl $\square b$ (to zbog grupa *klě, *žlě itd.) te pokolgéne (što će biti analoški prema izvedenicama na -jenje) - to imaju i neki susedni govori šumadijsko-vojvođanskog dijalekta.

Međutim, osim zamene jata, koja zapravo i ne predstavlja strukturno važno obeležje, jer se svodi samo na različitu distribuciju već postojećih jedinica u sistemu, a ne na njihovo ukidanje ili pojavljivanje novih, zbog 
čega je i lako govornicima da usvoje dvoizgovornost i da se po potrebi preključuju između ekavskog i jekavskog izgovora, mnogo su važnije druge karakteristike ovog dijalekta, koje su bilo stukturne prirode, kao akcentuacija ili morfologija i sintaksa, pa su zato teže podložne ,mimikriji“ nego što je to zamena jata, bilo da su, opet kao prozodija ili kao različite pojave na supfonemskoj razini, automatizmi artikulacione baze, pa ih govornici i govornice ni zbog toga ne mogu bez svesnog i dugotrajnog napora ispraviti. ${ }^{10}$ Upravo njih je imao u vidu i Peco kada piše da će ovi govori, i pored dejekavizacije, „odisati jekavskom strukturom“ (iznad).

To su, dakle, pre svega pojave na planu prozodije. Nekih i od njih su i sami govornici i govornice svesni, percipiraju ih kao obeležja svog dijalekta, ali za razliku od ijekavice, nisu u stanju da ih lako maskiraju; tê i neke druge pojave jednako percipiraju i govornici drugih dijalekata kao karakteristične regionalne markere; trećih pak nisu svesni ni sami govornici i govornice. Takvi prozodijski markeri jesu sama priroda akcenata (izrazita silaznost nizlaznih akcenata, jednosložnost uzlaznih akcenata) i čuvanje postakcenatskih dužina, koju osobinu i sami govornici ovog, a i govornice drugih dijalekata, laički percipiraju kao regionalni marker, ali zbog njenog sistemskog karaktera, kao i zbog automatizma artikulacione baze, nije ju lako moguće promeniti. S tim u vezi su i druge pojave na supfonemskom nivou, poput zatvorenog izgovora dugih vokala ili redukcija nenaglašenih vokala. To ostaju osobine i ,plićih“ nivoa dijalekta, dok se novoštokavsko prenošenje akcenata na proklitiku pak percipira kao obeležje „dubokog“ dijalekta, kao i ijekavska zamena jata, i to pod uticajem pravopisa, pa će se javiti samo kao sociolingvistički markirano sredstvo identifikacije, budući da ni tu nije zapravo reč o sistemskoj promeni, već samo o distribuciji akcenata, tj. povlačenju granica izgovornih reči (ali

\footnotetext{
${ }^{10}$ Usp. i kod Ivića: ,Za jezičku strukturu razlike u sistemu akcentuacije imaju mnogo veći značaj nego različita zamena jata. Uprkos tome usvojena je praksa da se pri klasifikaciji štokavskih govora polazi od zamene jata, a akcentuacija služi za podrazdele. Uzroci ovome su prvenstveno praktične prirode. Razlike u zameni jata mogu se lako uhvatiti i opisati, pa ih je stoga svesna i najšira publika, utoliko pre što se baš po ovoj crti razlikuju i narečja književnog jezika. Vrlo važnu ulogu igra i to što se zamena jata, za razliku od akcentuacije, ogleda i u običnom pismu. Taj fakat čini je ne samo upadljivijom za publiku već i podesnijom za istorijsku dijalektologiju, koja na osnovu pisanih spomenika izvodi zaključke o nekadašnjoj dijalekatskoj slici“, itd. (Ivić 2001: 83), kao i na drugom mestu: „Nije potrebno naročito dokazivati da akcenatske razlike među štokavskim govorima imaju daleko veći strukturalni značaj nego one u pogledu zamene ě. U jednom slučaju radi se o tome da li tonsko kretanje može imati distinktivnu vrednost i u kojim slogovima, i o tome koliko akcenata ima u nekom govoru i kako mogu biti raspoređeni, a u drugom slučaju sve se svodi na pitanje statističkog domašaja o tome u kojim se sve morfemama (uključujući tu, naravno, i korene reči) nalazi jedna od postojećih vokalskih fonema, a u kojima druga“ (Ivić 1994: 123-124).
} 
neće se izgubiti - ostaje u rezervoaru dijalekatskih osobina odakle se po potrebi uzima). I uopšte suprasegementna obeležja govora - pomenute velarizacije, nazalizacije i sl. - ostaće važni individualni i regionalni markeri, zbog automatizma artikulacione baze (i zbog toga što se prozodijske karakteristike govora najranije usvajaju itd.) teško eliminabilni. Automatizmu artikulacione baze ne mogu izbeći ni koartikulacione pojave poput fonoloških asimilacija (i to najpre u sandhiju, pošto tu pak pravopisni lik reči nema uticaj na izgovor kao unutar reči kao celine), kontrakcijâ vokala u hijatu, koji artikulaciona baza govornika ovog dijalekta ne trpi, i sl. Po

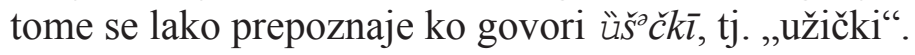

\section{Zaključci}

Ako pokušamo da sistematizujemo ono što je rečeno o aktuelnom stanju regionalne varijacije u našem slučaju, osobine ovog „dubokog“ „plitkog“ dijalekta možemo predstaviti u tabeli (1), u odnosu na njihovu perceptivnu istaknutost za same govornike i govornice i za govornike i govornice drugih dijalekata.

Tabela 1. Osobine „dubokog““ i ,plitkog“ dijalekta jugozapadne Srbije.

\begin{tabular}{|c|c|c|}
\hline & „duboki“ dijalekat & „,plitki“ dijalekat \\
\hline $\begin{array}{l}\text { sami govornici ovog, } \\
\text { kao i govornici drugih } \\
\text { dijalekata, percipiraju kao } \\
\text { obeležje }\end{array}$ & $\begin{array}{c}\text { ijekavski refleksi jata, } \\
\text { prenošenje akcenta na } \\
\text { proklitiku }\end{array}$ & $\begin{array}{l}\text { postakcenatske dužine, } \\
\text { nazalizacija i dr. } \\
\text { suprasegmentna obeležja }\end{array}$ \\
\hline $\begin{array}{l}\text { govornici ovog dijalekta } \\
\text { ne percipiraju, ali } \\
\text { govornici drugih } \\
\text { dijalekata mogu da } \\
\text { percipiraju kao obeležje }\end{array}$ & \multicolumn{2}{|c|}{$\begin{array}{c}\text { pojave na supfonemskom nivou, kao zatvorena } \\
\text { artikulacija vokala, redukcije vokala, velarna } \\
\text { artikulacija } l \text {, priroda akcenata (izraziti silazni akcenti) } \\
\text { i sl. }\end{array}$} \\
\hline $\begin{array}{l}\text { govornici drugih } \\
\text { dijalekata ne percipiraju, } \\
\text { ali govornici ovog } \\
\text { dijalekta percipiraju kao } \\
\text { obeležje svog dijalekta }\end{array}$ & $\begin{array}{l}\text { fonološke (automatske) } \\
\text { alternacije, naročito u } \\
\text { sandhiju, u hijatu i sl. }\end{array}$ & $\begin{array}{c}\text { uopšte glasovne } \\
\text { alternacije koje deluju u } \\
\text { okviru reči }\end{array}$ \\
\hline $\begin{array}{c}\text { ni govornici ovog, a } \\
\text { ni govornici drugih } \\
\text { dijalekata ne percipiraju } \\
\text { kao obeležje }\end{array}$ & \multicolumn{2}{|c|}{$\begin{array}{l}\text { morfonološke alternacije (npr. palatalizacija i sl.), } \\
\text { uopšte čitav morfološki i sintaktički sistem }\end{array}$} \\
\hline
\end{tabular}


Naravno, odnos između „dubokog“ i „plićih“ nivoa dijalekta nije tako kategorijalan, kako to tabela kao vizuelni prikaz sa svojim inherentnim ograničenjima sugeriše, već je reč o kontinuити u kome se pojedinačni idiolekti, ali i sve u tabeli navedene lingvističke osobine, nalaze nešto bliže ili nešto dalje jednom ili drugom polu. Naročito to vredi za osobine koje i sami govornici percipiraju kao dijalekatske (pod uticajem pravopisnog lika reči), ali ih zbog njihovog sistemskog karaktera, kao i možda zbog toga što ih govornici drugih dijalekata ne uočavaju nužno kao marker ovog, ređe ili teže svesno koriguju, kako to pokazuje isprekidana linija u tabeli (1). Iz tabele se, u svakom slučaju, vidi koje to osobine „dubokog“ dijalekta ovi govornici radije drže u ,rezervoaru“ osobina za „pregovaranje“ identiteta unutar zajednice, a nad kojima nemaju tu vrstu pragmalingvističke i sociolingvističke kontrole, već predstavljaju relativno stabilne markere regionalnog identiteta otvorene i „ka spolja“. U prvom slučaju, reč je o čisto statističkim, distributivnim karakteristikama nekih jedinica u sistemu, a u drugom o sistemskim odlikama ili automatizmima artikulacione baze, koji se rano usvajaju u govornoj zajednici i koje nije moguće bez velikog napora korigovati i bez promene koja bi narušila ceo sistem. Zato i imamo utisak da dijalekti ipak opstaju i uprkos uticaju standardnog jezika, jer opstaju njihove duboke sistemske karakteristike, čak i ako se neke ,površinske“, najuočljivije odlike nivelišu u odnosu na standard. Možda će naša dijalektologija u budućnosti morati zbog toga i da promeni konvencije i tradiciju na kojima počiva klasifikacija štokavskih dijalekata, tako da ove najuočljivije „površinske“ razlike među njima umesto u prvi potisne u neki manje istaknut plan, a da u fokus stavi njihove sistemske razlike (odnosno bliskosti).

Ovakve studije slučaja važne su, kao god i opisi pojedinačnih govora u tradicionalnoj dijalektologiji, zato što se iz njih, dakle, mogu izvući važne smernice i za neka šira teorijska pitanja, ali i za praktične probleme u različitim primenjenim lingvističkim disciplinama. Pre svega, u dijalektologiji, odn. arealnoj lingvistici i sociolingvistici - istraživanja savremenih „plićih" nivoa regionalne varijacije u govornom jeziku otkrivaju nam kakav je odnos između dijalekta i standardnog jezika odn. prestižnog idioma (da to nije jednostavan odnos zamene, već preključivanja/diglosije i sl., koji proizvodi i nove varijetete „,srednjeg sloga“), zatim šta je uopšte dijalekat i kako razumeti taj društvenoteritorijalni varijetet (koje pragmalingvističke i sociolingvističke funkcije on ima) u sistemu jezičkih varijanata, kao i osvestiti metodološke probleme prilikom njegovog pro- 
učavanja i posledične mogućnosti daljih istraživanja. U široj perspektivi, za sociolingvistiku i srodne discipline, iznimno važan je uvid i to da je identitet performativan i da se uvek aktivno „pregovara“, a ne samo iskazuje jezičkim sredstvima.

Za tipologiju jezika, sa svim što je napred rečeno u vezi, ovakva istraživanja imaju da pokažu i koji su to elementi jezika na različitim nivoima strukture perceptivno ili strukturno markiraniji i zašto, te kako se u odnosu na njih odvija jezička promena. Ujedno su to i važni uvidi za teorijsku lingvistiku uopšte, jer dokazuju npr. da zaista postoji realna razlika između fonoloških i morfonoloških alternacija u jeziku, odn. između različitih nivoa jezičke strukture (tj. „prve“ i ,druge artikulacije“), da to nisu samo teorijski konstrukti, već su stvarne pojave u jeziku kao sistemu, kao i za same govornike, itd. I konačno, u izvesnom smislu i najvažnije, jer se prožima kroz sve prethodno rečeno, jeste razumevanje prave uloge koju idiolekt ima u sistemu jezičke varijacije, odn. drugim rečima, uloge koju pojedinačni govornik ili govornica sâm ima u odnosu na svoj jezik, kao individua u zajednici, njene (meta)lingvističke svesti i njenih jezičkih izbora, stavova prema jeziku i sl.

Ne najmanje važno, aktuelno stanje regionalne varijacije nam pokazuje i to kakav je odnos između govornog i pisanog jezika (odnosno pravopisa), kako to pisani lik reči utiče na metalingvističku svest govornika i govornica, ali i obratno, o čemu ovde nismo imali prilike da više govorimo, kako govornici pismo prilagođavaju svojoj izgovornoj reči i kako u pismu komuniciraju druge jezičke markere regionalnog identiteta. (Kako su praktično svi govornici i govornice štokavskoga sada i pismeni i u sve većem su broju korisnici novih informacijskih i komunikacijskih tehnologija, na kojima sami proizvode sadržaje, pa je spontane i autentične jezičke građe svakim danom sve više, to će nam, ali sigurno i još mnoge druge manje poznate stvari o jeziku, sada najpre pokazati istraživanja jezika u novim medijima, poput pomenutog iznad u $\S 2.1$, koja onda u ovu oblast uvode i metode korpusne lingvistike.)

Na kraju - vrednost je poznavanja aktuelne dinamike jezičke varijacije za primenjene discipline poput obrazovne lingvistike (npr. nastave standardnog jezika u odnosu na „plitku“ i „duboku“ dijalekatsku bazu učenika), forenzičke lingvistike (npr. profilisanja i identifikacije govornika na osnovu markera regionalne pripadnosti) i sl., u tome što je, izradom konkretnih strategija za rešavanje praktičnih problema koji su u vezi s jezikom, a zasnovanih na njenom temeljnom poznavanju umesto na odsu- 
stvu znanja o tome kako danas izgleda naš dijalekatski mozaik i kako će se kretati u budućnosti, moguće značajno poboljšati kvalitet života ljudi.

\section{Literatura}

Belić, A. (1926/27). „Misli o prikupljanju dialekatskog materiala.“ Južnoslovenskifilolog 6: 1-10.

Bjelaković, A. (2018). „Whither variationist sociolinguistics in Serbia?“ Belgrade English Language and Literature Studies 10: 193-227.

Bošnjaković, Ž., ur. (2009). Govor Novog Sada. Sveska 1: Fonetske osobine. Novi Sad: Filozofski fakultet Univerziteta u Novom Sadu.

Bošnjaković, Ž. (2016). „Prilog srpskoj urbanoj dijalektologiji (jezičke napomene uz jedan dorćolski idiolekt).“ Južnoslovenski filolog 72 (3-4): 111136.

Božović, Đ. (2017). „Jezička politika i ideologija u kontekstu tranzicije.“ Primenjena lingvistika 18: 79-90.

Brozović, D. (2004). „O dijalektologiji kao jezikoslovnoj disciplini.“ $S u$ vremena lingvistika 57-58: 1-12.

Cvijetić, R. (2014). Rečnik užičkog govora. Beograd - Užice: Službeni glasnik i Učiteljski fakultet u Užicu.

Dragičević, M. \& S. Remetić (2001). „Srpska dijalektologija na početku XXI veka." U: Filozofsko-filološke nauke na početku 21. vijeka-problemi $i$ pravci razvoja: zbornik radova sa naučnog skupa (Banja Luka, 7-8. decembra 2001). Banja Luka: Filozofski fakultet u Banjoj Luci, 143-158.

Đukanović, P. (1995). „Govor Dragačeva.“ Srpski dijalektološki zbornik 41: $1-240$.

Đurović, R. (1980). „Refleksi jata u okolini Priboja.“ Srpski dijalektološki zbornik 26: 235-319.

Erdeljanović, J. (1902). Donje Dragačevo: antropogeografska proučavanja. [Naselja srpskih zemalja: rasprave i građa, knj. 1, ur. J. Cvijić]. Beograd: SKA.

Ivanović, M. \& M. Šešum (2009). „Jedan tip regionalne redukcije neakcentovanih slogova kao forenzički marker.“ ETRAN 2009. [Zbornik radova sa 53. konferencije za ETRAN, Vrnjačka Banja, 2009. Elektronski izvor].

Ivić, P., gl. red. (1981). Fonološki opisi... Sarajevo: ANUBiH.

Ivić, P. (1994). Srpskohrvatski dijalekti: njihova struktura i razvoj. Sremski Karlovci - Novi Sad: Izdavačka knjižarnica Zorana Stojanovića.

Ivić, P. (2001). Dijalektologija srpskohrvatskog jezika: uvod i štokavsko narečje. Sremski Karlovci - Novi Sad: Izdavačka knjižarnica Zorana Stojanovića. 
Ivić, P. (2009). Srpski dijalekti i njihova klasifikacija. Sremski KarlovciNovi Sad: Izdavačka knjižarnica Zorana Stojanovića.

Kašić, Z., S. Jovičić i M. Đorđević (2008). „Primena lingvističkih metoda u identifikovanju individualnih karakteristika govornika.“ Primenjena lingvistika 9: 68-74.

Kašić, Z. \& J. Đorđević (2009a). „Zašto je lingvistika postala forenzička veština?" U: D. Radovanović (ur.), Istraživanja u specijalnoj pedagogiji. Beograd: Fakultet za specijalnu edukaciju i rehabilitaciju Univerziteta u Beogradu, 469-482.

Kašić, Z. i J. Đorđević (2009b). „Ostaci automatizma artikulacione baze kao forenzički markeri.“ ETRAN 2009. [Zbornik radova sa 53. konferencije za ETRAN, Vrnjačka Banja, 2009. Elektronski izvor].

Kenda Jež, K. (2004). „Narečje kot jezikovnozvrstna kategorija v sodobnem jezikoslovju.“ Obdobja 22: Aktualizacija jezikovnozvrstne teorije na slovenskem: členitev jezikovne resničnosti. Mednarodni simpozij Obdobja-Metode in zvrsti, Ljubljana, 27.-28. november 2003. Ljubljana: Center za slovenščino kot drugi/tuji jezik pri Oddelku za slovenistiko Filozofske fakultete Univerze v Ljubljani, 263-276.

Kovačević, B. (2005). „Preključivanje između standardnog oblika srpskog jezika i njegovih dijalekata i između ekavskog i ijekavskog izgovora." Zbornik Matice srpske za filologiju i lingvistiku 48 (1-2): 283-297.

Lisac, J. (2003). Hrvatska dijalektologija 1: Hrvatski dijalekti i govori štokavskoga narječja i hrvatski govori torlačkog narječja. Zagreb: Golden marketing - Tehnička knjiga.

Lončar Raičević, A. \& N. Sudimac (2017). „Acoustic parameters of speech as forensic markers for speakers of Prizren-Timok dialect." U: A. Bošković i dr. (ur.), Dani Arčibalda Rajsa-Archibald Reiss Days, vol. 1. Beograd: Kriminalističko-policijska akademija, 465-475.

Lončar Raičević, A. (2018). „Akcenatski sistem govora Zlatibora.“ Srpski dijalektološki zbornik 65: 477-636.

Ljubešić, N., M. Miličević Petrović \& T. Samardžić (2019). „Jezična akomodacija na Twitteru: primjer Srbije.“ Slavistična revija 67 (1): 87-106.

Marković, S. (2011). „Govor Užičke Crne gore.“ Srpski dijalektološki zbornik 58: 337-670.

Marković, S. (2012). „Granice ijekavskih govora u zapadnoj Srbiji.“ Srpski dijalektološki zbornik 59: 383-484.[+ 3 karte.]

Marković, S. (2016). „Adverbi u govoru užičkog kraja.“ Srpski jezik 21: 502-520.

Marković, S. (2019). „O prozodijskim osobenostima deklinacije imenica u ijekavskim govorima zapadne Srbije.“ Južnoslovenski filolog 75 (1): 101-122. 
Milićević, M. Đ. (1876). Kneževina Srbija. Beograd: Državna štamparija. Moskovljević, M. (1929). „Današnja granica između ekavskog i jekavskog izgovora u Srbiji.“ Prilozi za književnost, jezik, istoriju i folklor 9: 109-122.

Muljačić, Ž. (1996). „Za relativistički pristup u proučavanju geneze i povijesti romanskih jezika." Suvremena lingvistika 41-42: 465-481.

Nikolić, M. (1972). „Govor sela Gorobilja (kod Užičke Požege).“ Srpski dijalektološki zbornik 19: 619-746.

Nikolić, M. (1991). „Govori srbijanskog Polimlja.“ Srpski dijalektološki zbornik 37: 1-548.

Peco, A. (1980). Pregled srpskohrvatskih dijalekata. [2. izd.]. Beograd: Naučna knjiga.

Petrović, T. (2015). Srbija i njen jug: ,južnjački dijalekti“ između jezika, kulture i politike. Beograd: Fabrika knjiga.

Petrović, T. (2016). „Dijalekat kao performans.“ U: R. Žugić (ur.), Dijalekti srpskoga jezika: istraživanja, nastava, književnost 1. Leskovac - Vranje: Leskovački kulturni centar i Pedagoški fakultet u Vranju Univerziteta u Nišu.

Remetić, S. (2017). „Srpska dijalektologija juče, danas i sutra.“ Južnoslovenski filolog 73 (3-4): 85-112.

Smole, V. (2004). „Nekaj resnic in zmot o narečjih v Sloveniji danes.“ Obdobja 22: Aktualizacija jezikovnozvrstne teorije na slovenskem: členitev jezikovne resničnosti. Mednarodni simpozij Obdobja - Metode in zvrsti, Ljubljana, 27.-28. november 2003. Ljubljana: Center za slovenščino kot drugi/tuji jezik pri Oddelku za slovenistiko Filozofske fakultete Univerze v Ljubljani, 321-330.

Sredojević, D. \& M. Čopa (2018). „Da li se dijalekatsko ujednačavanje u jednakom stepenu ostvaruje na fonetskom i na fonološkom nivou?" Zbornik Matice srpske za filologiju i lingvistiku 61 (1): 101-123.

Sudimac, N. (2016). „Sociofonetski pogled na srpske jezičke varijetete Percepcija. Akustika. Stavovi.“ Philologia Mediana 8: 555-586. 159-328.

Tešić, M. (1977). „Govor Lještanskog.“ Srpski dijalektološki zbornik 22:

Trajković, T. (2017). „Diglosija u srpskim dijalektima - stepen ispitanosti.“ U: Srpski jezik, književnost, umetnost: zbornik radova sa XI međunarodnog naučnog skupa održanog na Filološko-umetničkom fakultetu u Kragujevcu (28-29. X 2016), knj. 1: (Srpski) jezik u komunikativnoj funkciji. Kragujevac: Filološko-umetnički fakultet Univerziteta u Kragujevcu, 167-178. 


\section{Đorđe Božović}

\section{LINGUISTIC MARKERS OF REGIONAL IDENTITY: A VIEW FROM SERBO-CROATIAN}

Summary: The paper discusses a possible way of constructing the research paradigm and conducting research into the actual state of dialectal variation in one area of Serbo-Croatian. With the Ijekavian dialect of south-western Serbia as a case study, the paper brings an analysis of the evolution of the traditional dialect in contact with the Ekavian-based standard language, in order to point out the range of methodological issues that arise in the study of contemporary dialectal variation and the relationship of the standard language and non-standard dialects. In addition, the paper discusses the significance of such research for theoretical and applied linguistics alike. This includes, but is not limited to, traditional dialectology and areal linguistics, sociolinguistics and language typology, as well as such specific disciplines as forensic speaker identification.

Keywords: basis of articulation, deep and shallow dialect, spoken discourse, regional identity, the Ijekavian dialect in Serbia, areal linguistics, sociolinguistics, forensic linguistics. 